\title{
Analysis of Academic Supervision in Distance Learning During the Covid 19 Pandemic
}

\author{
Amelia Permatasari \\ UPT SMKN 3 Muara Enim, Indonesia \\ Email: ameliaper80@gmail.com \\ Bukman Lian \\ Universitas PGRI Palembang, Indonesia \\ e-mail: drbukmanlian@univpgri-palembang.ac.id \\ Alhadi Yan Putra \\ Universitas PGRI Palembang, Indonesia \\ e-mail: alhadian.putra@univpgri-palembang.ac.id \\ Article History: Received on 15 December 2021, Revised on 20 January 2022 \\ Published on 21 February 2022
}

\begin{abstract}
The purpose of this research is to identify and analyze: (1) distant learning at MAN 1 Muara Enim, and (2) academic supervision of remote learning during the covid-19 epidemic. This research employs qualitative methods with a descriptive approach. The study was conducted at MAN 1 Muara Enim, with data collected through observation, interviews, documentation, and a literature review with 64 instructors, two principals, and one Madrasah supervisor. The findings revealed that MAN 1 Muara Enim completed a series of good preparations, the academic supervision approach, which is typically done face-to-face, is now done remotely and is divided into two parts, manually verifying the lesson plan and synchronizing the online learning. This study contributes to the topic of Education Management, specifically academic supervision in sustaining teacher performance sustainability.
\end{abstract}

Keywords: Academic Supervision, Distance Learning, Covid-19

\section{A. Introduction}

Being an educator entails not only educating and instructing pupils, but also producing a variety of administrations in the form of tools and equipment, as well as selecting the best approach for teaching and learning activities. The responsibilities must be carried out optimally so that the output in the form of excellent pupils may be obtained ideally. The fundamental component that must be possessed to influence the direction of education as a whole is performance, which is part of educators' attempts to carry out their obligations responsibly (Julianto, 2019). Performance may be defined as an educator's best accomplishment in carrying out their professional obligations during a certain time period based on competency standards and criteria that are in agreement with a teacher's professional competence (Kartomo \& Slameto, 2016). Academic supervision activities are one way of promoting and enhancing educators' professional achievements.

Julianto (2019) reported that the principal's academic supervision activities had a 0.661 or 66.1 percent favorable influence on the work performance of educators in junior high schools throughout the North Raman District. Furthermore, Kristiawan and Hasanah (2019) discovered 
that academic supervision had a substantial influence on success. Madrasah Tsanawiyah Tabek, Pariangan District, Tanah Datar Regency educators In his study, there is a positive and significant effect between the two variables, as evidenced by the acquisition of a hypothesis test of 0.009 .

Lian, et al, (2020) conducted further academic supervision at SD Negeri 16 Gelumbang. Academic supervision in the study also revealed that the four stages of academic supervision activities resulted in an improvement in the job performance of the school's educators. The four processes are as follows: planning, academic supervision by the principal, feedback, and further action based on the outcomes of the academic supervision.

According to Ndapaloka et al. (2016), academic supervision provided by supervisors has a direct affect on teacher performance and achievement motivation, and the better the academic supervision, the more likely instructors are to be driven to improve their abilities.

In order to achieve an effective learning process, the Government Regulation of the Republic of Indonesia Number 19 of 2005 concerning National Education Standards (Government, 2005) Chapter IV Article 19 paragraph 3) stipulates that the planning and implementation of the learning process, evaluation of learning outcomes, and monitoring of the learning process must be carried out every year. adequate and good This verse clearly states that supervision is the most important component of applying effective learning and following current norms. Articles 23 and 2 reiterate the preceding paragraph. In particular, Article 23 states that the monitoring of the learning process in Article 19 (3) includes observation, supervision, assessment, report presentation, and performing the required follow-up activities. Furthermore, Article 2 defines the criteria created by BSNP and mandated by a ministerial rule for planning, implementing, assessing, and monitoring the learning process. In this article, the BSNP is tasked with developing a standard for monitoring the learning process, which will eventually be enshrined in a ministerial rule.

The legal foundation for the execution of supervision is established in the Minister of National Education's Regulation No. 19 of 2007 (Kemendiknas, 2007) about Standards for Education Provision by Primary and Secondary Education Units. The monitoring and assessment of point 1 must be carried out on a regular and ongoing basis by the directors/madrasah and school/madrasah supervisors, according to Permendiknas letter C. Continuous monitoring from the madrasah principal will instill excellent behaviors in the madrasa, making it a welcoming environment for great learning. Continuous monitoring by madrasah leaders increases not just the quality of the teaching and learning process, but also the efficiency of the teaching personnel. These specific circumstances have the potential to improve the finest educational services for students as consumers of education (Dian \& Prayoga, 2019).

When the emergence of a new virus known as Corona Virus Disease 19 was discovered towards the end of 2019, it became one of the worst records in health history (Covid 19). Corona virus is related to viruses such as Middle Eastern Respiratory Syndrome (MERS) and Severe Acute Respiratory Syndrome (SARS), which cause mild to severe disease and even death. In early December 2019, a patient in Wuhan, Hubei Province, China, became infected with this virus for the first time. The COVID-19 epidemic then expanded so swiftly that the WHO labeled it a pandemic on March 11, 2020. "This is the first pandemic caused by a coronavirus," WHO Director-General Tedros Adhanom Ghebreyesus said in an official address to the media at a conference report in Geneva, Switzerland. This was followed by an official notification from 
Volume 3 (2) 2022

E-ISSN: 2723-6919 P-ISSN: 2746-0827

the Indonesian government on March 1, 2020, stating that the Covid-19 outbreak was declared a national catastrophe by the President through the Head of the National Civil Protection Agency in accordance with Law Number 2 of 2007. Moving forward, the government has formed the Working Group for the Acceleration of Covid-19 Handling to coordinate national and regional efforts to prevent the virus from spreading further.

The designation of Covid 19 as a national tragedy has had a significant impact on many elements of society, including the face of education. The government created a strategy to encourage pupils to learn from home, which is being adopted to avoid the spread of Covid-19 (Kasan Erdogan). The Ministry of Education and Culture released Circular No. 15 of 2020 (Kemendikbud, 2020b) about Guidelines for the Implementation of Learning from Home in an Emergency Period of Corona Virus Disease to safeguard students' rights to education services in an emergency. The propagation of the Corona virus, which requires learning to take place from home and is referred to as Distance Learning.

According to Nugroho (2020), distance education, also known as PJJ, is a series of educational and learning activities that are carried out indirectly or remotely using various communication media, such as regulation no. 109, which was listed by the Minister of Education and Culture of the Republic of Indonesia in 2013. Please keep that in mind. It is created using a variety of learning media, including PCs and Android, in forms such as video conferencing, e-learning, Google classroom, quizzes, padlets, Microsoft teams, Zoom, WhatsApp, Google Meet, and many others.

The major aim, however, is to obey the government's directives and defend the educational world while disregarding the government's support for social distancing tactics during the Covid-19 epidemic. The Minister of Education and Culture followed up on this policy with Circular Letter Number 4 of 2020 (Kemendikbud, 2020a) concerning the Implementation of Educational Policies, which stated that it should provide meaningful learning experiences for students during the Covid-19 pandemic, without being hampered by demands to provide all curriculum services for grade progress and graduation. Emphasis should be placed on life skills education, especially those relevant to the Covid-19 epidemic, as well as learning from home. Learning activities and assignments may differ across students depending on their unique interests and circumstances, including access to housing/study facilities. Meanwhile, evidence and learning results from home activities should be provided with feedback from educators that gives valuable motivation and support without giving a predefined score. During the Covid-19 pandemic, schools have the authority to continue referring to the national curriculum that has been implemented thus far; o refer to the national curriculum with simplified KI and KD for special conditions determined by the director of the book research and development agency; or make curriculum simplification independently. The Ministry of Instruction and Culture took this move to ensure that every educational unit can give good education to pupils even in the middle of the continuing Covid-19 epidemic.

The Directorate General of Islamic Religious Education of the Ministry of Religion of the Republic of Indonesia responded to the Covid-19 pandemic by issuing Decree of the Director General of Islamic Religious Education Number 2791 of 2020 (Dirjenpendis, 2020), which provides guidelines for learning emergency response plans for madrasas. Distance learning cannot be compared with face-to-face instruction, hence this step was taken. Distance education can help students maintain their health, but it is not as perfect as face-to-face teaching because distance education is not as effective as traditional education, and this condition forces 
Volume 3 (2) 2022

E-ISSN: 2723-6919 P-ISSN: 2746-0827

educational institutions to improve curriculum and develop additional studies with appropriate and appropriate materials to make learning more effective. Furthermore, the Decree of the Director General of Islamic Education Number 2791 of 2020 contains four curricular strategies that have been implemented to overcome learning difficulties caused by school closures, namely curriculum content reduction, subject rationalization, changing assessments, and distance education. During the Covid19 epidemic, the emergency curriculum policy at madrasas stressed parts of curriculum adjustments and distant learning that focused on adjusting goals linked to skill development, instructional materials, learning methodologies, and evaluation of learning results.

There is a lot of infrastructure that can support distance learning for free through various discussion rooms such as Whatsapp, Learning House, Our Desk, ICANDO, Google for education, Microsoft office 365, Quipper school Zenius, Sekolahmu, Cisco Webex, and even the previously paid Teacher Room, at the start of the Covid-19 Pandemic period as the beginning of distance learning provided free facilities to access the learning infrastructure. Teaching and learning activities may still be done out in a face-to-face format by using free video conferencing platforms such as Zoom, Webex, and Google Meet. The Indonesian government uses television on the TVRI channel to offer instructional programs on a national scale. The educational level of broadcast programming is determined by the Indonesian curriculum. Teaching and learning activities can still be carried out in the traditional manner, beginning with questions and answers, progressing to presentations and even assigning homework.

The Covid-19 pandemic scenario necessitates a shift in the type or method of monitoring or supervision of educators, particularly in the application of academic supervision. The supervision model, which was previously included in the supervised class, is now overseen using a separate system due to changes in the system and style of learning. According to Dalyono in Renata et al (2018), constant and ongoing coaching is a technique to transform educators into professionals with exceptional talents who are valued, respected, and acknowledged for their professionalism. Making an educator into a skilled worker requires more than just providing upgrading, training, or the chance to study again; educators must also be paid attention to in other areas, such as performing monitoring, in order for teachers to be satisfied in their roles as educators.

Furthermore, Kasmawati (2020) mentioned that supervision is one of the attempts to enhance the quality of instructors teaching in the classroom as a form of developing the potential of these teachers in order for these teachers to achieve better teaching performance. Academic supervision must be included in the oversight of each learning process.

According to the Work Guide for Madrasah Heads During the Covid-19 Pandemic (Kemenag, 2020), learning supervision is still carried out during the Covid-19 pandemic in order to guarantee the quality of learning in Madrasahs, adapting to pandemic situations and conditions in order to improve learning management, increase ability to use teaching materials, and optimize communication collaboration between teachers and students in teaching and learning activities. Direct learning support can enhance the quality of exceptional learning chances for pupils as a result of this rise.

Restrictions on academic supervision implementation in the midst of the Covid-19 outbreak can be overcome by employing other methods to ensure that supervision is carried out 
Volume 3 (2) 2022

E-ISSN: 2723-6919 P-ISSN: 2746-0827

successfully and efficiently. According to study (Elfidawati, 2020), monitoring activities may be carried out with a weekly activity form by checking in on a regular basis for observation, discussion, and verification. This is a possible answer to issues with supervision implementation in the midst of the Covid-19 outbreak. Despite the fact that many previous studies have shown that academic supervision services are the principal's responsibility as a managerial function that has a positive impact on improving student work performance in the learning process, no one has thoroughly examined the process of changing academic supervision in the field. The application of academic monitoring by the principal differs from one madrasa to the next. The differences in academic supervision implementation are attributable to the various barriers encountered by each institution. As a result, while providing academic assistance to educators, particularly through remote learning, administrators must establish and use acceptable supervisory standards. The principal, as the school's supervisor, is also responsible for ensuring the learning process's application throughout the Covid-19 epidemic. Even in the middle of the Covid-19 epidemic, academic supervision activities may be used to ensure excellent and quality learning. During the Covid19 epidemic, many schools are unable to give maximal distance education. MAN 1 Muara Enim is one of several schools that may organize online learning during the Covid 19 epidemic while adhering to the national curriculum that has been applied so far. As a result, the purpose of this study is to examine how the principal of the MAN 1 Muara Enim school implements distant learning and academic supervision of distance learning during the Covid-19 epidemic.

\section{B. Methods}

The goal of this study was to learn more about the Head of Madrasah Aliyah Negeri 1 Muara Enim's strategy for preparing teachers and students to face distance learning, as well as the Head of Madrasah's strategy as a supervisor and supervisor in carrying out academic supervision during distance learning. The researchers employed qualitative research with a descriptive technique in this study (Gunawan, 2013); (Shidiq \& Choiri, 2019). Data sources gathered through observation activities, interviews, and documentary studies, which will then be examined to develop a hypothesis. Following the collection of data, the researcher analyzes, parses, evaluates, and interprets the significance of the observations made at the study site.

\section{Results and Discussion}

MAN 1 Muara Enim has agreed to use Distance Learning beginning March 23, 2020. MAN 1 Muara Enim was hosting the National Based Madrasah Final Examination (UAMBN) for class XII students at the time. MAN 1 Muara Enim decided to keep UAMBN online since the conditions were becoming increasingly risky due to the possibility of exposure to MAN 1 Muara Enim pupils from Covid 19.

Firmansyah, M.Pd, Deputy Head of Madrasah for Curriculum, collaborated with the Head of Madrasa, Mrs. Deni Ariani, S.Ag, to hold UAMBN online since it is not safe to utilize an airconditioned Computer Lab and collecting students in the room will expose them to Covid 19. And it was decided that the UAMBN would be continued online from the students' homes/locations utilizing their unique gadgets. At the time, UAMBN media was delivered online via the official UAMBN server. In addition, during each test session, the school offers a Google Form link that is sent via Whatsapp Group to anticipate if there is a server network difficulty at that moment. MAN 1 Muara Enim has two days remaining to finish the UAMBN 
online, which will be followed by students from their individual homes, on March 23 and 24, 2020.

Then, on Wednesday, March 19, 2020, at 14.00 WIB in the teacher's room of the Head of Madrasah Aliyah Negeri one Muara Enim Deni Ariani, S.Ag conducted a coordination meeting with all teachers and Madrasah employees to avoid the spread of the covid-19 epidemic. In He stated at the coordination meeting that, in accordance with Circular No. 264 of 2020 regarding the prevention of the spread of the 2019 corona virus disease in the Regional Office of the Ministry of Religion of South Sumatra Province, from March 18 to 31, 2020, to conduct distance learning from each other's homes by limiting the distance. interactions with one another.

Deni Ariani, S.Ag., stated that E-learning is the ideal answer when Covid-19 is widespread in the community, but it requires the participation of all components in the Madrasa, particularly operators, homeroom instructors, teachers, and students, in order to be carried out successfully. "All teachers are required to be able to master the program properly, give learning materials, evaluate students, tutorials, videos, practice problems, and student worksheets utilizing media that each topic teacher has produced," he stated (Interview results September 6, 2021).

Then, based on circular letter No. B-355/Ma06.11.01/PP.006/04/2020, remote learning, which was initially restricted to March 31, 2020, was extended. In this letter, it is explicitly mentioned that all home learning activities are prolonged until April 21 and must be completed in the same manner as KBM in school, as well as attendance. The distinction is that all of this must be done via online media, with no face-to-face encounters.

The Covid-19 epidemic has prompted the education world to shift the teaching and learning process from school to home in order to break the chain of the corona virus's propagation. Learning From Home, which is separated into two categories, namely Online Distance Learning and Off-Network Distance Learning, urges educators to be better prepared in carrying out the teaching and learning process, so that the spirit of learning itself stays relevant and focused. Since the introduction of remote learning at MAN, which was conducted on March 23, 2020 via a teacher council meeting, the educators of MAN 1 Muara Enim have also been very busy in making many preparations. One of the lecturers remarked in an interview that remote learning inspires him to enhance the technology that would be utilized throughout the online teaching and learning process. Educators require the use of technology, notably the internet, smart phones, and laptop computers, to enable distant learning. Participate in the socialization of distance learning to students of MAN 1 Muara Enim in order for them to be better prepared for the PJJ, which will take place at that time (Nopita Lindra Depi, interview result Wednesday, September 15, 2021). He also mentioned that when he found out that PJJ will be hosted at MAN 1 Muara Enim, he began producing teaching materials in the form of videos and powerpoints, with Ms.word as the primary focus at the moment.

Gusniarti, the Teacher of the Cultural Arts Department of MAN 1 Muara Enim, claimed in an interview on Saturday, September 18, 2021, that the PJJ preparations he was undertaking at the time were making observations or observations. He went on to say that his observations included observing students' readiness to engage in distance learning, observing whether or not all students had electronic devices, and considering solutions for students who did not have electronic devices to take turns taking school assignments and doing these assignments at home. According to observations from the madrasah, when distance learning began, the 
Volume 3 (2) 2022

E-ISSN: 2723-6919 P-ISSN: 2746-0827

majority of MAN 1 Muara Enim students had their own personal equipment. Those who do not have their own electronic devices can still participate in distance learning by using the electronic devices of their parents or siblings, so that during the Covid-19 pandemic, distance learning at MAN 1 Muara Enim runs smoothly using Google Classroom and e-learning, despite occasional signal problems for pupils that reside nearby.

Because MAN 1 Muara Enim is the only State Aliyah Madrasah in Muara Enim Regency, it is a popular choice for students who wish to continue their education after graduating from Junior High School or Madrasah Tsanawiyah. As a result, many kids from beyond the Muara Enim sub-district attend this school. According to Ms. Puspalena, S.Pd, the Deputy Head of Madrasah for Student Affairs, around 70\% of MAN 1 Muara Enim students come from outside the Muara Enim sub-district (Interview Results, Wednesday, September 1, 2021). This is what prompted MAN 1 Muara Enim to combine the usage of two online learning tools, namely https://elearning.kemenag.go.id/web and the Google Classroom platform.

At the time, the online learning application, https://elearning.kemenag.go.id/web, was quite new. According to the madrasa operator, Kumedi, MAN 1 Muara Enim was hampered by insufficient facilities at the time in order to access E-learning. Then, MAN 1 Muara Enim was duped into employing hosting as an e-learning server (Interview Results Monday, September $6,2021)$. There were various challenges that madrasah operators experienced in helping the course of learning in e-learning at the time, including the server going down when hundreds of students accessed the e-learning. The next barrier is the restricted capacity of files that may be posted at https://elearning.kemenag.go.id/web. The operator is busy erasing files submitted by the maple instructor so that subsequent learning is not delayed by the topic teacher adding files for learning. And the most significant barrier at the time was that E-learning was a little more difficult to utilize. Many pupils who live outside the Muara Enim sub-district experience significant difficulties accessing e-learning.

At the time, the Head of MAN 1 Muara Enim took numerous crucial efforts to facilitate distant learning. Deni Ariani, S.Ag stated that MAN1 Muara Enim did not have an e-learning server at the time. "We decided to search for a third party to supply server services so that e-learning could be utilised." S.Ag. Deni Arini The results of the interviews will be available on September 6, 2021.

Furthermore, Heni Rosalina, S.Pd, Deputy Head of Madrasah for Infrastructure, said that the school allowed MAN 1 Muara Enim instructors to utilize LCDs, projectors, and classrooms to create movies for instructional materials. The school also supports the borrowing of school computer laboratories for pupils who do not have gadgets or are experiencing signal issues (Interview results September 9, 2021). Madrasah operators will also assist students who wish to utilize the school's computer facility to access lessons via Google Classroom. "We also grant quotas to needy kids during the COVID-19 epidemic before receiving government quota help," stated Deni, Ariani, S.Ag.

The choice was made to integrate two learning platforms, namely https://elearning.kemenag.go.id/web and Google classroom, and this resulted in the creation of a new difficulty with the system for monitoring the course of teaching and learning activities during the distant learning time. Supervision as part of academic supervision is one of the most significant aspects of increasing educational quality; it must still be carried out in any existing learning settings in order to be maintained as an attempt to ensure the quality of learning and 
avoid learning loss for students. "At the time, I coordinated directly with the Madrasah Head on the optimum way of academic supervision, similar to what MAN 1 Muara Enim may do for remote learning supervision," Firmansyah, MPd said (Interview results September 6, 2021) (Gusmiyati et al, 2021; Lisliana et al, 2020).

Based on the research findings, it was discovered that the principal's managerial function at MAN 1 Muara Enim in controlling the quality of education through academic supervision to ensure the continuity and control of the quality of learning during the Covid 19 pandemic, which requires the learning process to be transferred from home, was carried out properly. According to the findings of an interview with the Head of MAN 1 Muara ENIM in 2020, he carried out academic monitoring at his institution in the midst of the Covid-19 outbreak by requesting educators to submit reports on Online Teaching and Learning Activities. Face-toface meetings were not possible at the time, even though they were confined to teaching personnel. The mood is unsettling and unfavorable. There was no vaccination at the time, and the number of Covid-19 victims was growing by the day. First and foremost, there is health and safety. However, unsupervised distant learning is also impossible. So, Deni Ariani, S.ag, and I discussed finding the suitable supervisory solution as a substitute for academic supervision, which is generally done face-to-face, stated Deni Ariani, S.Ag (Interview result 6 September 2021). We do this with the team in two ways: we check the RPP and we check the Online KBM Report. Prior to this, we socialized everything through formal meetings, which were done online at the time, Deni Ariani, S.Ag. stated.

Furthermore, based on the findings of field, it appears that academic supervision activities are carried out in accordance with the madrasa's vision, purpose, and goals in order to manage the professional educators of MAN 1 Muara Enim. The madrasah's head devises an academic supervision program, beginning with the formation of a supervision team. The supervision team is made up of the head of the madrasah and the deputy head of the madrasa in the field of curriculum who have been granted a letter of assignment to assist with academic supervision. The established supervision team then developed academic supervision objectives, determined academic supervision targets, created a supervision timetable, and researched the supervision tools to be utilized. The academic supervision program's goals, objectives, timelines, and tools are developed by the supervision team. The paper will serve as the foundation and reference for academic monitoring by the madrasa's head and the supervision team (Devi et al, 2021; Desrina et al, 2020).

Because learning is done online, academic monitoring, which is generally done in person, is substituted by individual reports for each educator at MAN 1 Muara Enim. The online KBM report employed by MAN 1 Muara Enim is a way to ensure that no learning is lost during the Covid-19 epidemic. The Online KBM report is developed in this manner by a team comprised of the Head of Madrasah, Supervisors, and Deputy Heads of Madrasas for Curriculum Sector, and is carried out on a constant basis as part of academic supervision/supervision during distance learning. We also continue to hold formal meetings as part of the educator and educational staff training at MAN 1 Muara Enim, which we also do online. I usually tell people that the learning process in the madrasa is being carried to the home, which is not a simple task if it is not approached positively and with full attention. All teachers are expected to conduct learning and madrasa programs in a professional and trustworthy way. The process of distant learning should not be taken lightly. What has been determined by the Madrasa Learning and Assessment mechanism in the emergency period to prevent the spread of Covid 19 issued by the Director General of Education on March 24, 2020 must be carried out as soon as possible 
so that students can continue to study in corridors and definite goals like normal face-to-face classes," Deni added (Results of interview 6 September 2021).

Drs. Surya Patala, the Madrasah supervisor at the Ministry of Religion Office, also supervises learning at MAN 1 Muara Enim. In an interview conducted on September 14, 2021, at the Office of the Ministry of Religion of Muara Enim Regency, he claimed that as a supervisor, he is also required to participate in preserving the continuity of distance learning at MAN 1 Muara Enim. He indicated that the supervision was carried out in accordance with the learning material employed. Initially, MAN 1 Muara Enim relied on official E-learning provided by the Indonesian Ministry of Religion. However, due to several issues with e-learning, the school eventually opted to employ Google Classroom. I then met with the school to determine the best method for overseeing learning. At the start of remote learning, reporting consisted solely of photos/screenshots of items supplied by educators at MAN 1 Muara Enim to Google Classroom. Then, with the Head of MAN 1 Muara Enim and the Wakamad for Curriculum at the time, we finally reviewed what should be included in an accountability report for educators who have fulfilled their commitments as distant learning instructors. As a result, it was decided to incorporate individual daily absences of educators, as well as student performance reports, in a tabular style that will be simplified. Then I requested that not just picture proof/screenshots of the teacher's material be included as evidence of the report, but that some of the student work or exams be included in the accountability report as well. There are various difficulties to overcome when it comes to obstacles. Distance learning will almost definitely not be implemented as smoothly as the administration anticipates. Drs. Surya Patala remarked, However, I ensure that MAN 1 Muara Enim is effective in adopting distant learning by carrying out continuous monitoring of the learning process at MAN 1 Muara Enim.

The online learning report for MAN 1 Muara Enim is based on field research and includes a list of attendance instructions for instructors, Work from Home Reports, Collection of Learning Materials, and proof of many student tasks. In the implementation of supervision, the head of the madrasa positions himself in a position to establish a healthy mood and climate, so that the implementation of supervision may run smoothly and the learning process can flow smoothly. The implementation of supervision carried out by the madrasa's head can operate smoothly and generate optimal outcomes if the implementation of supervision carried out by the madrasa's head is carried out efficiently (Mulyasa, 2004). Continuous attempts to oversee the madrasah principal would result in a healthy academic culture in the madrasa, creating an academic atmosphere conducive to a quality learning process.

Academic supervision is carried out at MAN 1 Muara Enim by continuous monitoring (every day) and by keeping instructors accountable through online KBM reports. In the application of academic supervision, assessment is the most crucial last step that must be completed in order to optimize success outcomes. According to Firmansyah M.Pd, if there are deficiencies or mistakes in the lesson plan, the lesson plan will be returned to the instructor concerned with recommendations or instructions for errors or deficiencies established in the lesson plan. Similarly, if there is a shortfall or incomplete report in the Online KBM Report, it will be returned to the instructor in question for correction, according to Firmansyah M.Pd (Interview results, Monday 6 September 2021).

Based on the findings of the documentation research, the Head of Madrasah MAN 1 Muara Enim has fulfilled his responsibility as a supervisor, and it is envisaged that the madrasa head can support educators in teaching and learning activities (Yusuf et al, 2021). According to the 
Volume 3 (2) 2022

E-ISSN: 2723-6919 P-ISSN: 2746-0827

findings of researcher interviews with educators at MAN 1 Muara Enim, the head of the madrasa at MAN 1 Muara Enim always has a positive attitude toward all educators, pupils, and madrasa inhabitants. During the implementation phase, both educators and school administrators encountered certain challenges, including the continuation of online academic and administrative oversight, given that MAN 1 Muara Enim was still adjusting to Distance Learning at the time (March 2020 to July 2021).

\section{Conclusion}

Based on the findings of the study and debate, it is clear that the Madrasas analyzed are prepared to tackle distance learning, as indicated by the learning process being carried out as if it were a regular class prior to the Covid-19 epidemic, despite the fact that the implementation is online. The Madrasah Head's policy has been in conformity with the demands of distant learning. Several tactics are employed in remote learning implementation, including working fast to overcome challenges or barriers faced in distance learning during the Covid-19 pandemic, both in terms of infrastructure, both students and instructors, and the competency of the MAN 1 Muara Enim teacher. MAN 1 Muara Enim educators responded well to school policies aimed at boosting teacher competency during the Covid-19 pandemic, as evidenced by the consistent usage of Google classroom media and video-based teaching materials in the teaching and learning process throughout the Covid-19 pandemic. During the age of distant learning During the Covid-19 epidemic, the Madrasas studied continued to conduct out academic supervision, as shown by evidence of verifying RPP and online KBM Report collecting, as well as evidence of academic supervision outcomes evaluation. Academic supervision in the field is carried out in line with the stages of academic supervision implementation, including planning, execution, and assessment. The technique employed is consistent with the stated objectives, namely, to ensure that there is no loss of learning in distant learning during the covid 19 epidemic, and therefore the ultimate aim of MAN 1 Muara Enim is achieved. The objective is to raise an Islamic youthful generation that is knowledgeable, successful, and environmentally conscious.

\section{E. Acknowledgement}

Thanks to Principal of UPT SMKN 3 Muara Enim, MAN 1 Muara Enim, Rector Universitas PGRI Palembang, Director of Postgraduate Program and Chief of Study Program Management of Education Universitas PGRI Palembang and friends who have supported us to do this valuable project.

\section{References}

Desrina, D., Fitria, H., \& Mulyadi, M. (2020). The Relationship between Principal Supervision and Interpersonal Communication with the Work Ethic of Teachers. Journal of Social Work and Science Education, 1(2), 161-167. https://doi.org/10.52690/jswse.v1i2.45

Devi, D., Harapan, E., \& Wardiah, D. (2021). The Implementation of Principal's Supervision in SD Negeri Tungkal Ilir Banyuasin (Teacher's Competency Development Study). Journal of Social Work and Science Education,2(1), 60-68. https://doi.org/10.52690/jswse.v2i1.206 
Dian, D., \& Prayoga, A. (2019). Supervisi Akademik Kepala Madrasah di Madrasah Aliyah Darussalam Sumedang [Academic Supervision of the Head of Madrasah at Madrasah Aliyah Darussalam Sumedang]. Briliant: Jurnal Riset Dan Konseptual, 4(4), 548. https://doi.org/10.28926/briliant.v4i4.413

Dirjenpendis. (2020). Keputusan Direktur Jenderal Pendidikan Islam Nomor 2791 Tahun 2020 Tentang Panduan Kurikulum Darurat Pada Madrasah [Decree of the Director General of Islamic Education Number 2791 of 2020 concerning Emergency Curriculum Guidelines for Madrasas].

Elfidawati, E. (2020). Peningkatan Kedisiplinan dan Kualitas Pembelajaran Guru Pada Masa Pandemi Covid-19 Melalui Supervisi Akademik Di SD 009 Kuala Terusan Pangkalan Kerinci [Improving Discipline and Quality of Teacher Learning During the Covid-19 Pandemic Through Academic Supervision At 009 Kuala Terusan Elementary School, Pangkalan Kerinci]. Jurnal Kepemimpinan Dan Pengurusan Sekolah, 5(2), 171-179. https://doi.org/10.34125/kp.v5i2.564

Gunawan, I. (2013). Metode Penelitian Kualitatif [Qualitative Research Methods]. 1-14.

Gusmiyati, G., Lian, B., \& Fitria, H. (2021). Principal's Supervision in Improving Teacher's Performance. Journal of Social Work and Science Education, 2(1), 83-94. https://doi.org/10.52690/jswse.v2i1.209

Hasanah, M. L., \& Kristiawan, M. (2019). Supervisi Akademik dan Bagaimana Kinerja Guru [Academic Supervision and How Teachers Perform]. Tadbir : Jurnal Studi Manajemen Pendidikan, 3(2), 97. https://doi.org/10.29240/jsmp.v3i2.1159

Julianto, H. (2019). Pengaruh Pelaksanaan Supervisi Akademik Kepala Sekolah Dan Pemanfaatan Media Pembelajaran Terhadap Kinerja Guru SMP [The Influence of the Implementation of Principal Academic Supervision and Utilization of Learning Media on the Performance of Middle School Teachers]. Jurnal Lentera Pendidikan Pusat, 4(1).

Kartomo, A. I., \& Slameto, S. (2016). Evaluasi Kinerja Guru Bersertifikasi [Certified Teacher Performance Evaluation]. Kelola: Jurnal Manajemen Pendidikan, 3(2), 219. https://doi.org/10.24246/j.jk.2016.v3.i2.p219-229

Kasmawati. (2020). Pemanfaatan Aplikasi Google Form dalam Pelaksanaan Supervisi Akademik di Masa Pandemi Covid-19 pada Sekolah Binaan di Kabupaten Takalar [Utilization of the Google Form Application in the Implementation of Academic Supervision in the Covid-19 Pandemic Period at Targeted Schools in Takalar Regency]. Jurnal Sipatokkong BPSDM Sulawesi Selatan, 1(2), 137-142.

Kemenag. (2020). Panduan Kerja Kepala Madrasah Pada Masa Covid-19 Kementerian Agama RI [Work Guide for Madrasah Heads During the Covid-19 Period Ministry of Religion of the Republic of Indonesia]. Kementerian Agama RI.

Kemendikbud. (2020a). Surat Edaran Menteri Pendidikan dan Kebudayaan Nomor 4 Tahun 2020 Tentang Pelaksanaan Kebijakan Pendidikan dalam Masa Darurat Penyebaran Coronavirus Disease (Covid-19) [Circular of the Minister of Education and Culture 
Number 4 of 2020 concerning the Implementation of Educational Policies in the Emergency Period for the Spread of Coronavirus Disease (Covid-19)].

Kemendikbud. (2020b). Surat Edaran Sekretaris Jenderal Kementerian Pendidikan dan Kebudayaan Nomor 15 Tahun 2020 Tentang Pedoman Penyelenggaraan Belajar Dari Rumah dalam Masa Darurat Penyebaran Corona Virus Disease (Covid-19) [Circular of the Secretary General of the Ministry of Education and Culture Number 15 of 2020 concerning Guidelines for Organizing Learning from Home in an Emergency Period for the Spread of Corona Virus Disease (Covid-19).

Kemendiknas. (2007). Permendiknas No 19 Tahun 2007 , Standar Pengelolaan Pendidikan oleh satuan pendidikan [Permendiknas No 19 of 2007, Standards for Management of Education by education units].

Lian, B., Fitria, H., \& Zulfakar. (2020). Implementasi Supervisi Akademik dalam Meningkatkan Kinerja Guru [Implementation of Academic Supervision in Improving Teacher Performance]. Jurnal Manajemen, Kepemimpinan, Dan Supervisi Pendidikan) P-ISSN: 2548-7094 E-ISSN 2614-8021, 5(2).

Lisliana, L., Fitria, H., \& Rohana, R. (2020). The Implementation of Class Supervision and Its Positive Impact. Journal of Social Work and Science Education, 1(2), 146-160. https://doi.org/10.52690/jswse.v1i2.43

Ndapaloka, V., Hardyanto, W., \& Prihatin, T. (2016). Pengaruh Supervisi Akademik Pengawas dan Kepemimpinan Kepala Sekolah Melalui Motivasi Berprestasi Sebagai Mediasi Terhadap Kinerja Guru SMK Negeri Kabupaten Ende [The Effect of Academic Supervision of Supervisors and Principal Leadership Through Achievement Motivation as a Mediation on Teacher Performance at State Vocational Schools in Ende Regency]. Educational Management, 5(1), 42-54.

Nugroho, G. B. (2020). Peran Guru Bimbingan dan Konseling Dalam Pendampingan Belajar Siswa Selama Pembelajaran Online [The Role of Guidance and Counseling Teachers in Assisting Student Learning During Online Learning]. Psiko Edukasi, 18(1), 73-83.

Pemerintah, P. (2005). Peraturan Pemerintah No. 19 Tahun tentang Standar Nasional Pendidikan [Government Regulation No. 19 Years on National Education Standards].

Renata, Wardiah, D., \& Kristiawan, M. (2018). The influence of headmaster's supervision and achievement motivation on effective teachers. International Journal of Scientific and Technology Research, 7(6), 44-49.

Shidiq, U., \& Choiri, M. (2019). Metode Penelitian Kualitatif di Bidang Pendidikan [Qualitative Research Methods in Education]. In Journal of Chemical Information and Modeling, 53(9).

Yusuf, M., Fitria, H., \& Mulyadi, M. (2021). The Influence of Teacher's Supervision and Professionalism on Teacher's Performance. Journal of Social Work and Science Education, 1(3), 234-240. https://doi.org/10.52690/jswse.v1i3.110 